\title{
A Cytoprotection of Rat Hepatocytes Mediated by the Intracellular Calcium
}

\author{
Toshihiro Tachibana , Akiko Kusumoto ,Yukari Ueda , Zenei Taira
}

Faculty of Pharmaceutical Sciences, Tokushima Bunri University, Tokushima 770-8514, Japan

(Accepted for publication, Junuary 20, 2006)

\begin{abstract}
The role of intracellular $\mathrm{Ca}^{2+}$ in $\mathrm{CCl}_{4}$ hepatotoxicity in rats was clarified by measuring detailed changes in serum ALT values and intracellular $\mathrm{Ca}^{2+}$ after $\mathrm{CCl}_{4}$ administration. Serum ALT activity clearly increased up to a peak value at 1 day after i.p. administration of $\mathrm{CCl}_{4}$ at $0.2 \mathrm{ml} / \mathrm{kg}$, and then decreased to the control level after 3 days. Intracellular $\mathrm{Ca}^{2+}$ responded to $\mathrm{CCl}_{4}$ intoxication with a biphasic increase. The first intracellular $\mathrm{Ca}^{2+}$ peak increased up to 5.6-fold the control level at 1 hour, and the second $\mathrm{Ca}^{2+}$ peak 6.5-fold at 3.5 days. The results showed that the first $\mathrm{Ca}^{2+}$ increase might be attributable to a signal arising from the extent of hepatic injury. The second $\mathrm{Ca}^{2+}$ increase might act to activate cellular protective functions. We discussed that sustained intracellular $\mathrm{Ca}^{2+}$ and S100A4 increases may be involved in autoprotection or adaptive cytoprotection, namely susceptibility against a toxication.
\end{abstract}

Key words: Basic study, hepatotoxicity, intracellular $\mathrm{Ca}^{2+}$

\section{Introduction}

The physiological roles of $\mathrm{Ca}^{2+}$ ions are to regulate a wide variety of cellular processes such as hormonal responses, enzymatic activation, cell division and cell death. The intracellular $\mathrm{Ca}^{2+}$ also plays a potential role in carbon tetrachloride (CCl4) induced liver injury. Schanne et al. (1979) concluded that intracellular accumulation of $\mathrm{Ca}^{2+}$ ion is the final common pathway by which toxic cell death occurs. However, we have found that the intracellular $\mathrm{Ca}^{2+}$ concentration ([Ca $\left.{ }^{2+}\right]$ ) increase induced by $\mathrm{CCl}_{4}$ injury acts the roles of cytoprotectives (Taira et al., 2002). The serum ALT activity clearly increased up to a peak value of 29fold the control value 1 day after i.p. administration of $\mathrm{CCl}_{4}$ at 0.2 $\mathrm{ml} / \mathrm{kg}$, and then decreased to its control level after 3 days. Then, $\left[\mathrm{Ca}^{2+}\right]_{\mathrm{i}}$ in hepatocytes prepared from $\mathrm{CCl}_{4}$ administered rats increased steeply to the first peak one hour after $\mathrm{CCl}_{4}$ administration, and then decreased to the control level 2 hours later. The values gradually increased again to reach to the second peak 3 days after $\mathrm{CCl}_{4}$ administration before again returning to the control level in 4 days. We have further concluded that the second $\mathrm{Ca}^{2+}$ increase acts to activate cellular protective functions, based on the comparative study used drugs, including nifedipine, verapamil, thioridazine, dantrolene, quinacrine, compound 48/80, baicalin, cimetidine, and cycloheximide.

In this study, we further investigated the role of $\left[\mathrm{Ca}^{2+}\right]_{\mathrm{i}}$ in $\mathrm{CCl}_{4}$ hepatotoxicity in rats.

\section{Chemicals}

Materials and Methods

$\mathrm{CCl}_{4}$, bovine serum albumin (BSA), sodium dodecyl sulfonate (SDS) and fura 2-AM were purchased from Wako Co. (Osaka, Japan). All other reagents were of the highest grade available from commercial sources.

\section{Animal treatment}

Male Donryu ratswere obtained from SLC Co. Ltd. (Shizuoka, Japan), and had free access to a commercial diet and water during the experimental period. Some rats were given an i.p. injection of $0.2 \mathrm{ml} / \mathrm{kg}$ of $\mathrm{CCl}_{4}$ as $20 \%(\mathrm{v} / \mathrm{v}) \mathrm{CCl}_{4}$ in olive oil on the first day (day 0), and then blood was drawn daily from the tail vein of these etherized rats with a heparinized syringe. Serum ALT activity was measured spectroscopically using a diagnostic kit from Wako Pure Chemical Industries Ltd. (Osaka, Japan).

\section{Isolation of hepatocytes}

Hepatocytes were prepared from livers in normal or CCl4 fed rats by circulating collagenase perfusion of the liver. Cells were washed, and resuspended in Krebs-Ringer bicarbonate, $\mathrm{pH} 7.4$, containing $5 \mathrm{mM}$ glucose and $1 \mathrm{mM} \mathrm{CaCl}_{2}$. The hepatocytes were prepared to $3 \times 10^{6}$ cells $/ \mathrm{ml}$. The cells were loaded with fura2$\mathrm{AM}$, and cells displaying high fluorescence were selected for sorting by flow cytometer

\section{Assay of cell viability in hepatocyte suspension}

Propidium iodide (PI) fluorescence was used to quantitate percent cell viability in suspensions of isolated hepatocytes. Freshly isolated hepatocytes (5,000 cells/ml) were incubated in KrebsRingers buffer (pH 7.4), containing $2 \mathrm{mg} / \mathrm{ml} \mathrm{BSA,} 1 \mu \mathrm{M}$ PI and 25 mM NaHEPES. Total fluorescence of PI was monitored with fluorometer using $520 \mathrm{~nm}$ excitation and $605 \mathrm{~nm}$ emission filters. After measuring basal fluorescence (A), 50 mM CCl4 was added, and total fluorescence was measured for 150 minutes. Individual experiments were terminated by adding $375 \mathrm{mM}$ digitonin to permeabilize all cells, and a final fluorescence measurement (B) was obtained 20 minutes later. Percent cell viability (V) at time points during the incubation was calculated by the formula where $\mathrm{X}$ is fluorescence at any given time: $\mathrm{V}(\%)=100 \mathrm{x}(\mathrm{B}-\mathrm{X}) /(\mathrm{B}-\mathrm{A})$.

\section{Pharmacokinetics of salicylamide (SAM)}

$\mathrm{CCl}_{4}(0.2 \mathrm{ml} / \mathrm{kg}$ ) was administered intraperitoneally at $20 \%(\mathrm{v} /$ v) solution in olive oil. At 0-5 days after $\mathrm{CCl}_{4}$-treatment, rats were anesthetized with diethyl ether, and polyethylene cannulas were inserted into the femoral artery and vein. SAM was intravenously administered and blood was collected by $90 \mathrm{~min}$. SAM was extracted from blood samples and its fluorescence was measured at em. $415 \mathrm{~nm}$ and ex. $335 \mathrm{~nm}$. Pharmacokinetic parameters of SAM were calculated by the moment analysis. AUC were calculated as follows: $\operatorname{AUC}(0-\infty)=\operatorname{AUC}(0-t)+C(t) / k_{e}$. Where $t$ is the time of the last plasma concentration and $\mathrm{k}_{\mathrm{e}}$ is the elimination rate constant calculated as the slope of the plasma concentration. AUC(0-t) was calculated using the trapezoidal rule with linear interpolation.

\section{Assay of aniline metabolism}

Aniline metabolism was measured by a 96-well microplate assay using the phenol-indophenol method. Each aliquot contained 0.3 
M Tris chloride buffer $\mathrm{pH}$ 7.4, $0.15 \mathrm{M} \mathrm{MgCl}_{2}$, microsomes, $5 \mathrm{mM}$ $\mathrm{NADPH}$ and $5 \mathrm{mM}$ NADH. The reaction was completed at $37^{\circ} \mathrm{C}$ with samling at some interval times by 9 min. The sample was treated to stop the reaction. After centrifugation, the supernatant was mixed with phenol (1\% w/v) and $1 \mathrm{M} \mathrm{Na}_{2} \mathrm{CO}_{3}$, and allowed to stand at $37^{\circ} \mathrm{C}$ for $30 \mathrm{~min}$. The absorbance of the solution was measured at $620 \mathrm{~nm}$. The Michaelis constant, $\mathrm{K}_{\mathrm{m}}$, and the maximum velocity constant, $\mathrm{V}_{\max }$, were obtained from the Hofstee plot.

Results are expressed as mean \pm s.D. Statistical significance between two mean values was assessed using Student's $t$-test for paired data. A difference was considered significant when $P$ was 0.05 or less.

\section{Results}

\section{Cell viability in hepatocyte suspension}

Cell viability in suspensions of hepatocytes was measured by total fluorescence of PI. Since fluorescence of PI is enhanced after nuclear binding, we used PI fluorescence to monitor the percent of nonviable cells in suspensions of hepatocytes.

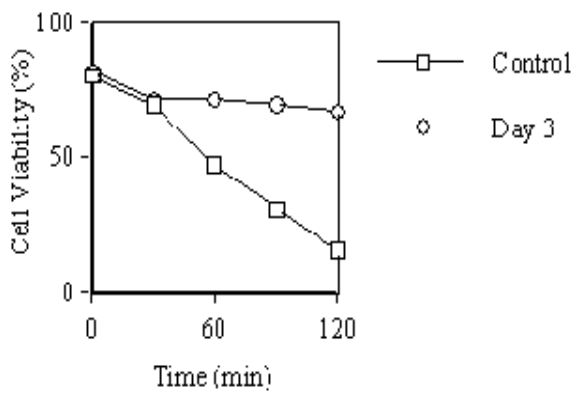

Fig. 1. Cell viability in hepatocyte suspension after i.p. CCl4 administration.

Loss of cell viability after PI began with a characteristic latency of about 30 minutes, and 50\% cell killing occurred after about an hour (Fig. 1). Thus, the kinetics of cell killing for freshly isolated hepatocytes resembled closely for day 1 cultured hepatocytes. Using the PI assay, cell killing after exposure was determined.

\section{Effect of $\mathrm{CCl}_{4}$-induced hepatotoxicity on pharmacokinetics of SAM}

Fig. 2(a) shows the time-courses of plasma concentrations of SAM, administered intravenously at a dose of $137 \mathrm{mg} /$ $\mathrm{kg}$ to rats at various days after a single ip administration of $\mathrm{CCl}_{4}(0.2 \mathrm{ml} / \mathrm{kg})$, and then analyzed using the moment analysis. The results of AUC showed that the liver function in the rats decreases significantly at days one and three after the administration of $\mathrm{CCl}_{4}$, that is, an increase of AUC.

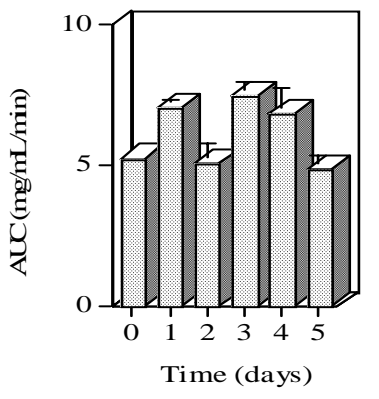

Fig. 2. Changes of AUC values of SAM in rats administered $\mathrm{CCl}_{4}$.

Although AUC values at days three and four also increased up to 41.4 and $32.2 \%$ of the control value, respectively. These results may show that the decreased liver function at day one is directly attributable to damage by $\mathrm{CCl}_{4}$-induced hepatic injury, but at later

days may be attributed to the physiological changes effected by the prolonged hepatotoxication of $\mathrm{CCl}_{4}$, such as regeneration.

\section{Effect of $\mathrm{Ca}^{2+}$ on P450 activity}

We studied the inhibitory effects of $\mathrm{Ca}^{2+}$ ion on metabolism of aniline using liver microsomes from acetone-treated rats. The apparent kinetic parameters were estimated using Hofstee plots, as shown in Fig.3.

The apparent kinetic parameters for aniline metabolism were determined to be a $\mathrm{K}_{\mathrm{m}} 0.171 \mathrm{mM}$ and $\mathrm{V}_{\max } 1.595 \mathrm{mM} / \mathrm{min}$. Furthermore, at $5 \mathrm{mM} \mathrm{Ca}^{2+}, \mathrm{V}_{\max }$ value decreased $54 \%$ less than that of $\mathrm{Ca}^{2+}$ free.

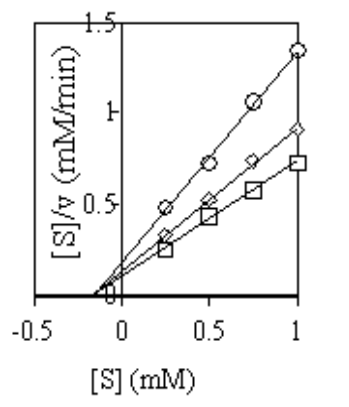

\section{Discussion}

As mentioned above, Schanne et al. (1979) concluded that intracellular accumulation of $\mathrm{Ca}^{2+}$ ion is the final common pathway by which toxic cell death occurs. However, we showed that the intracellular $\mathrm{Ca}^{2+}$ increase acts the role of the cytoprotection after the $\mathrm{CCl}_{4}$ intoxication. In this study, we conformed that the cells induced the intracellular $\mathrm{Ca}^{2+}$ increase have protective against PI intoxication. Mehendale et al. (1994) showed this phenomenon involved in autoprotection, whereby prior exposure to a small dose of a chemical results in protection against a subsequently administered lethal dose of the same compound; and further that such protection against $\mathrm{CCl}_{4}$ toxicity is closely associated with active hepatocyte regeneration. We also showed, using pharmacokinetic measurements, in which the metabolic activity of SAM decreases in rats in such a regenerating period after $\mathrm{CCl}_{4}$ administration at $0.2 \mathrm{ml} / \mathrm{kg}$ (Taira et al., 2004). Therefore, the present study is first demonstration in vivo that intracellular $\mathrm{Ca}^{2+}$ acts to protect cells or life from intoxication.

\section{Acknowledgements.}

This work was supported by MEXT.HAITEKU, 2003-2007.

\section{References}

1) Taira Z, Yabe K, Hamaguchi Y, Hirayama K, Kishimoto M, Ishida S, Ueda Y (2004) Effects of Sho-saiko-to extract and its components, baicalin, baicalein, glycyrrhizin and glycyrrhetic acid, on pharmacokinetic behavior of salicylamide in carbon tetrachloride intoxicated rats. Food Chem Toxicol 42, 803-807

2) Taira Z, Yabe K, Miyake S, Inui Y, Hashida M, Yamada S, Ueda Y. (2002)

3) Intracellular Ca2+ mediating biodefense signal on CCl4induced Autoprotection. Nippon Yakurigaku Zasshi. 2002 120, 119P-121P.

3) Mehendale HM, Thakore KN, Rao CV (1994) Autoprotection: stimulated tissue repair permits recovery from injury. J Biochem Toxicol 9, 131- 139

4) Schanne FA, Kane AB, Young EE, Farber JL (1979) Calcium dependence of toxic cell death: a final common pathway. Science 206, 700-702 